\title{
Company Bankruptcy Prediction Coal Mining Sector Listed on the Indonesia Stock Exchange and Its Impact on Stock Prices
}

\author{
Erik Priambodo', Augustina Kurniasih ${ }^{2}$ \\ 1,2Universitas Mercu Buana, Indonesia \\ Email: erickpriambodo@gmail.com
}

\begin{abstract}
This study aims to prove whether coal mining sector companies have the potential to go bankrupt if measured using the Altman Z-Score model. The study also analyzed the effect of the components of financial ratios in the Altman Z-Score model on stock prices. The research sample is 17 coal mining companies listed on the Indonesia Stock Exchange for the 2015-2019 period. The results of the calculation of the Z-Score value show that several coal mining companies have the potential to go bankrupt. Using the panel data regression approach, it was found that the Z-Score value had a significant effect on stock prices. Partially, the EB/TA ratio has a significant effect on stock prices. The ratios of WC/TA, RE/TA, and MVE/BVL have no significant effect on stock prices.
\end{abstract}

Keywords: Z-Score, Bankruptcy, Altman, Stock Price.

\section{A. INTRODUCTION}

Coal price fluctuations that occurred in the 2015-2019 period had an impact on coal mining companies where the income received fluctuated and even decreased. Earnings Before Interest and Tax/EBIT (Earning Before Interest and Tax) PT. Adaro Energy Tbk (ADRO), one of the largest coal producers in Indonesia, fell to 659 million USD compared to 2018 which reached 820 million USD. Financial performance of PT. Bayan Resources Tbk (BYAN) with EBIT 696 million USD in 2018 decreased to 311 million USD in 2019. Financial performance of PT. Bukit Asam Tbk (PTBA) and PT. Toba Bara Sejahtera Tbk (TOBA) also experienced the same thing from 2018-2019. The performance of 5 (five) coal mining companies listed on the IDX with the largest EBIT is presented in the following table.

Table 1. EBIT of Coal Mining Companies

\begin{tabular}{|c|l|c|c|c|c|c|c|}
\hline \multirow{2}{*}{ No } & \multicolumn{1}{|c|}{ Company } & \multirow{2}{*}{ Code } & \multicolumn{5}{|c|}{ Year } \\
\cline { 4 - 8 } & & ADRO & 279.973 & 546.973 & 536.438 & 820.998 & 659.103 \\
\hline 1 & PT. Adaro Energy Tbk & A & $\mathbf{2 0 1 6}$ & $\mathbf{2 0 1 7}$ & $\mathbf{2 0 1 8}$ & $\mathbf{2 0 1 9}$ \\
\hline 2 & PT. Bayan Resources Tbk & BYAN & $(68.182)$ & 29.503 & 420.083 & 696.732 & 311.625 \\
\hline 3 & PT. Delta Dunia Makmur Tbk & DOID & $(5.789)$ & 60.710 & 86.703 & 107.902 & 34.878 \\
\hline 4 & $\begin{array}{l}\text { PT. Tambang Batubara Bukit } \\
\text { Asam Tbk }\end{array}$ & PTBA & 193.099 & 203.468 & 335.639 & 469.516 & 392.429 \\
\hline 5 & PT. Toba Baa Sejahtera Tbk & TOBA & 39.144 & 25.984 & 60.196 & 97.282 & 62.869 \\
\hline
\end{tabular}

Source: idx, 2020

In line with the decline in financial performance, the debt of coal mining companies also tends to increase in the 2015-2019 period. PTBA's debt increased by $17 \%$ for the 2015-2019 period. The largest increase in debt was TOBA from USD 127 
million in 2015 to USD 370 million in 2019 or an increase of $191 \%$. Some of the companies that experienced significant debt are presented in the following figure.

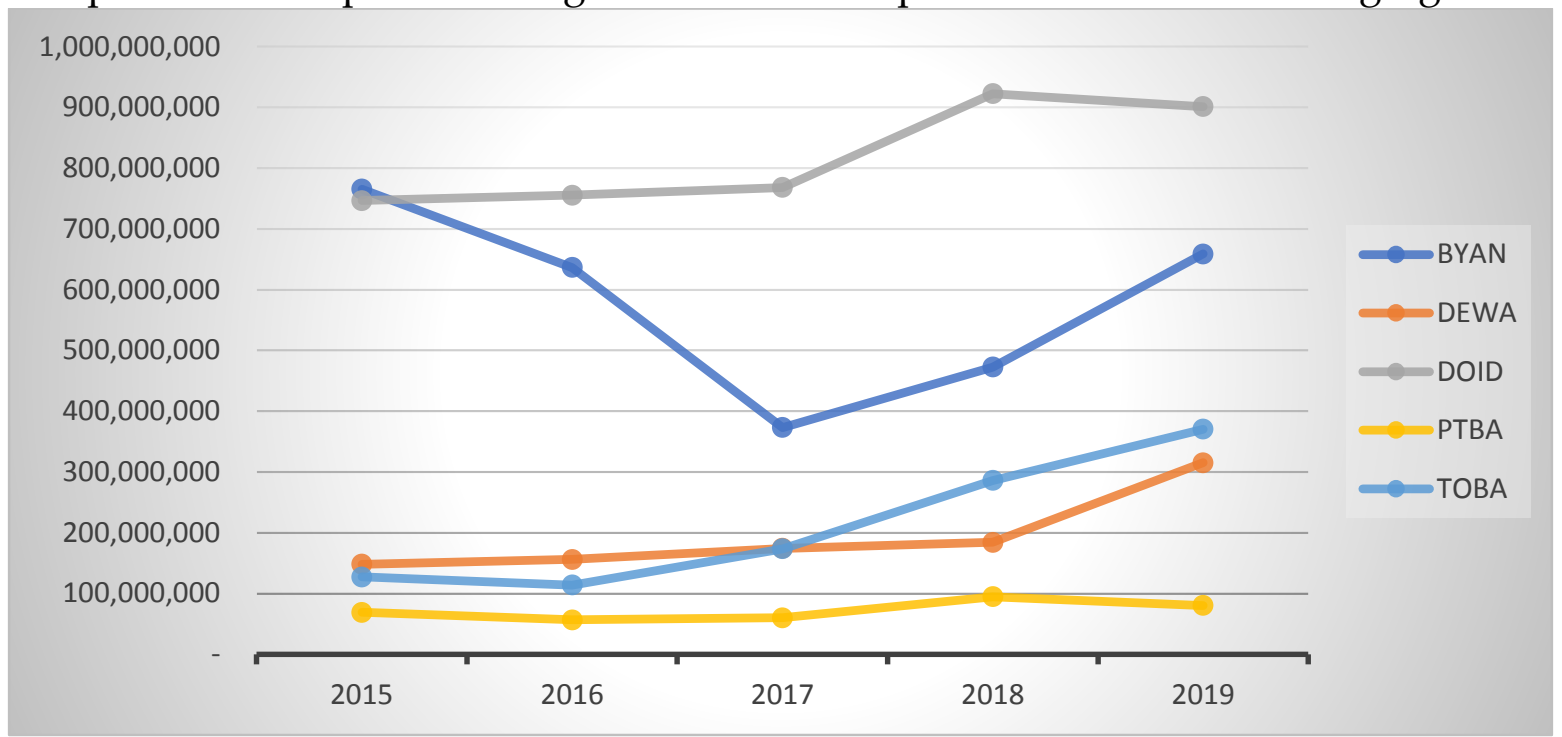

Figure 1 Coal Mining Company Debt 2015-2019

Fluctuations or even a decrease in EBIT value accompanied by an increase in debt amounts to a warning for coal mining companies whether the company can settle its obligations with unstable financial performance conditions. If this condition continues and there are no efforts to overcome it, the company will suffer losses due to lack of profit and increased debt and will cause financial distress which can lead to bankruptcy.

Gosh (2013) states that corporate bankruptcy is characterized by a prolonged and continuous decline in the company's financial condition. The condition of financial distress (financial distress) occurred before the bankruptcy and triggered the company's financial condition to worsen. If the state of the company is approaching financial distress, usually the company's management will close all activities within the company, be it production activities or other operational activities before bankruptcy. Bankruptcy is also often called company liquidation or company closure or insolvency. Bankruptcy as a failure is defined as a financial failure and economic failure (Adnan \& Kurniasih, 2000).

On the other hand, since the 1990s the coal mining sector has been reopened for foreign investment, so that this sector has experienced an increase in domestic production, exports, and sales. In recent years there has been a rapid increase in domestic coal demand and sales as the Indonesian government is committed to its ambitious energy programs, one of which is coal power generation (coal as an energy source because Indonesia has quite a lot of coal reserves). As a result, coal mining share prices increased (indonesia-investments.com, April 2018). The program is known as Domestic Market Obligations (DMO) which requires coal mining companies to sell coal to the domestic industry in a certain amount. 


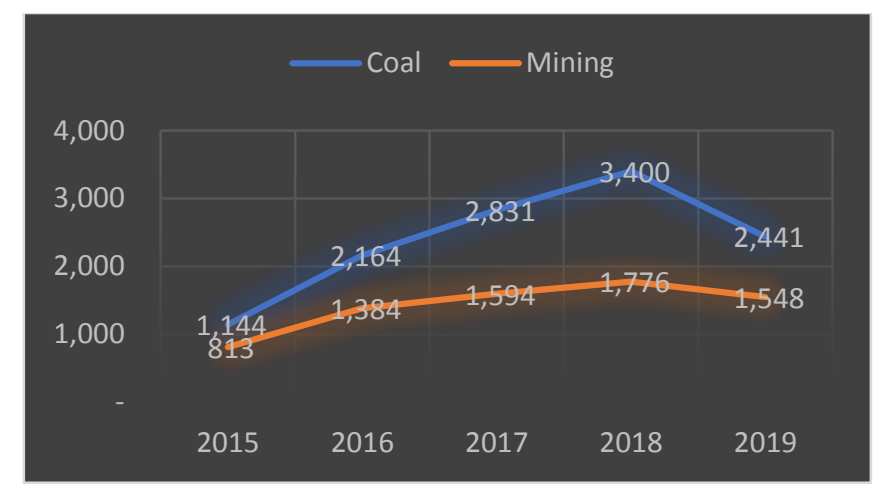

Figure 2. Share Prices of Coal Mining Companies in 2015-2019

The DMO program caused domestic coal sales to increase rapidly. This causes the share price of coal to increase. In fact, the average price of coal companies is higher than that of mining companies in general (Figure 2).

Stock price fluctuations can be influenced by various factors, one of which is the company's health condition. One of the characteristics of an unhealthy company is experiencing financial difficulties. Z-score is one approach to assessing the company's health condition. Several previous studies have empirically proven the effect of ZScore on stock prices. Wulandari et al. (2017), Syamni et al (2018), and Ramadhan \& Wuryani (2018) found the Z-score has a significant effect on stock prices. However, Karaca \& Ozen (2017), Ardian \& Khoirudin (2014), and Iladina et al. (2018) found that the Z-Score has no significant effect on stock prices.

This study aims to analyze the prediction of the bankruptcy of coal mining companies through the Altman Z-score approach. In addition, to analyze the impact of the Z-score and its components on the company's stock price.

\section{B. LITERATURE REVIEW}

Financial Distress is defined as a condition of a decline in the company's financial performance which indicates the beginning of bankruptcy (Platt, 2002). According to Prihadi (2011), bankruptcy is a condition where the company is unable to pay off its obligations. Meanwhile, according to Hanafi (2009), short-term financial difficulties are temporary and not so severe. But such difficulties if left untreated can develop into non-solvable difficulties (debts are greater than assets).

Several methods to measure a company's financial performance related to financial distress or bankruptcy include the Altman Z-Score Method, the Springate Method, the Ohlson Method, the Zmijewski Method, and the Grover Method. Of these methods, the most frequently used is the Altman Z-Score. Primasari (2017) concludes that the level of suitability of the predictions generated by the Altman Z-scores model is based on the results of hypothesis testing where the coefficient of determination and the significance value of F of the Altman Z-Score model are the highest values compared to other models such as Zmijewski, Springate, and Grover Altman Z method. -Score can also assess the condition of the company more evenly because it considers the number of outstanding shares, share prices, and retained earnings 
which are not found in other methods such as Springate which only measures income (Caroline and Laturette, 2019).

The Altman Z-Score method was developed in 1968 by Edward I. Altman. This method uses discriminant analysis statistical techniques where the critical score for this model is 1.8. If the $Z$ value $<1.8$, then the company is a bankrupt company, while if the $Z$ value is between 1.81-2.99, then the company is included in the gray area company (cannot determine whether the company is healthy or bankrupt). Then if the $Z$ value $>2.99$, the company is healthy (Altman, 1968).

Altman's research (1995) modifies his model so that it can be applied to all types of companies, such as manufacturing companies, non-manufacturers, and bond issuing companies in developing countries (emerging markets). In the modified Z-Score, Altman eliminates the $X 5$ variable (sales/total asset.) because this ratio varies widely in industries with different asset sizes. The modified Z-Score equation becomes:

\section{$\mathrm{Z}=6,56 \mathrm{X} 1+3,26 \mathrm{X} 2+6,72 \times 3+1,05 X 4$ \\ $\mathrm{Z}=$ Bankruptcy index modified; \\ $\mathrm{X} 1$ = Working capital/total asset; \\ $\mathrm{X} 2$ = Retained earnings/total asset; \\ $\mathrm{X} 3=$ Earning before interest and taxes/total asset; \\ $\mathrm{X} 4=$ Book value of equity/book value of total debt.}

The category of healthy and bankrupt companies is based on the Z-Score value of the Modified Altman model, namely: If the $Z$ value $<1.1$ then it is a bankrupt company. If the value $1.1<Z<2.6$ then it is included in the gray area (cannot be determined whether the company is healthy or bankrupt). If the $Z$ value $>2.6$, it is a company that is not bankrupt.

From several studies have been carried out, showing different results or conclusions regarding the relationship between bankruptcy potential and stock prices. Ardian and Khoiruddin (2014) and Illadina et al. (2018) states that the Z-Score does not affect the stock price of manufacturing companies listed on the Indonesia Stock Exchange (IDX). Karaca and Ozen (2017) also find that the Altman Z-Score bankruptcy prediction has no significant effect on the share price of the tourism sector on the Turkey Istanbul Stock Exchange (BIST).

These results are different from Syamni et al. (2018) which states that the Altman Z-Score bankruptcy prediction has a significant effect on oil and gas mining stock prices on the IDX. Ramadhan and Wuryani (2018) also state that the prediction of the bankruptcy of Altman Z-Score affects the stock price of state-owned companies on the Indonesia Stock Exchange.

Another study discusses more deeply the effect of financial ratios forming the Altman Z-Score on stock prices. Ardian and Khoiruddin's (2014) research on the manufacturing sector found that WC/TA and S/TA had a negative and significant effect on stock prices, EBIT/TA had a positive effect, RE/TA, and MVE/BVL was known to not affect stock prices. Sukmawati et al. (2014) found that EBIT/TA and MVE/BTL have a significant effect on stock prices. Meanwhile, WC/TA, RE/TA, and $\mathrm{S} / \mathrm{TA}$ (sales to total assets) do not have a significant effect on the stock prices of companies in the banking sector. Radityatama (2019) found that WC/TA and RE/TA 
had no significant effect on stock prices. In contrast, EB/TA and MVE/BTL were found to have a significant effect on stock prices of plantation sector companies listed on the IDX.

The framework for this research is presented in Figure 3.

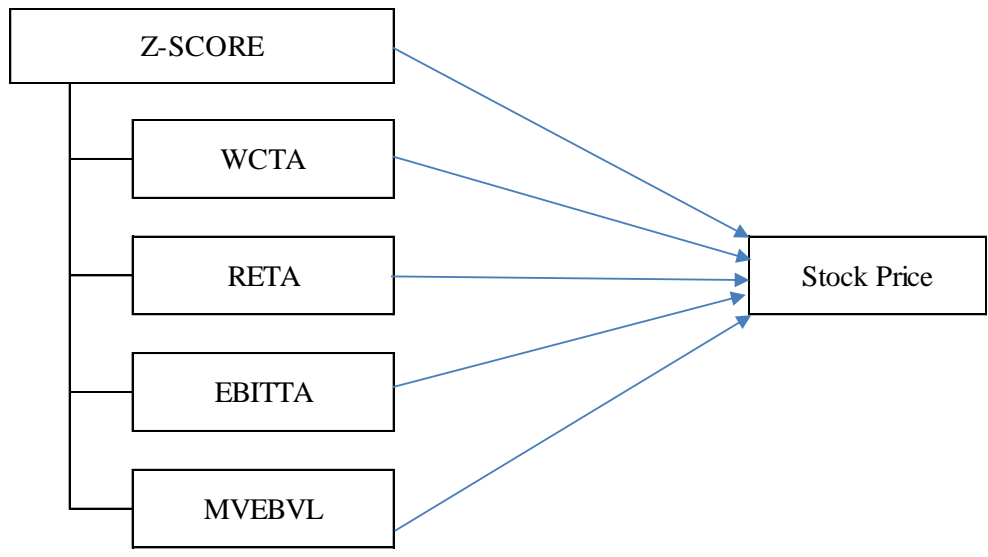

Figure 3. Framework

\section{METHOD}

This research includes quantitative research that will examine the effect of independent variables on the dependent variable. In other words, this research is causality research.

The population of this study is companies engaged in coal mining and listed on the Indonesia Stock Exchange. In 2020 there are 22 companies. Sampling was carried out purposively with the criteria (1) The company was consistently listed on the IDX and included in the coal mining sector in 2015-2019 and (2) Financial Statements for the 2015-2019 period were available. Samples that meet the criteria are 17 companies so that 85 observation data are obtained.

The variables in this study and their measurements are presented in Table 2. It can be seen that all research variables are ratio scale data. In addition, the research data is secondary, annual, cross-sectional, and time-series data.

Table 2. Variable Measurement

\begin{tabular}{|c|c|c|c|}
\hline No & Variable & Measurement & Scale \\
\hline 1 & Stock Price $(\mathrm{Y})$ & Closing price listed at the end of the year & Ratio \\
\hline 2 & Z-Score $\quad(X)$ & Z-Score Analysis results & Ratio \\
\hline 3 & WC/TA & Working Capital/Total Asset & Ratio \\
\hline 4 & RE/TA & Retained Earnings/Total Asset & Ratio \\
\hline 5 & $\mathrm{~EB} / \mathrm{TA}$ & $\begin{array}{l}\text { Earnings Before Interest and Taxes /Total } \\
\text { Asset }\end{array}$ & Ratio \\
\hline 6 & MVE/BVL (X4) & $\begin{array}{l}\text { Market Value of Equity/Book Value of } \\
\text { Total Liabilities }\end{array}$ & Ratio \\
\hline
\end{tabular}

The data were analyzed using descriptive and inferential statistical approaches. Through descriptive statistics, the potential for bankruptcy of coal mining companies will be known. Inferential statistics were performed using a 
regression approach to determine the effect of Altman Z-Score and its components on stock prices.

\section{RESULT AND DISCUSSION}

The results of calculating the Z-score of coal mining companies in the 20152019 period are presented in Table 3. It can be seen that most of the companies are in a healthy condition, namely 12 out of 17 companies (70.59\%). There are 3 mining companies (17.65\%). While in the gray area there are 2 companies $(11.76 \%)$.

Table 3. Coal Mining Company Z-Score 2015-2019

\begin{tabular}{|c|c|c|c|c|c|c|}
\hline Stock Code & $\mathbf{2 0 1 5}$ & $\mathbf{2 0 1 6}$ & $\mathbf{2 0 1 7}$ & $\mathbf{2 0 1 8}$ & $\mathbf{2 0 1 9}$ & Prediction \\
\hline ADRO & 4.18 & 3.78 & 4.19 & 4.15 & 3.74 & Good \\
\hline ARII & -3.67 & -4.53 & -3.77 & -5.02 & -4.72 & Distressed \\
\hline BSSR & 3.31 & 4.86 & 8.18 & 5.71 & 4.98 & Good \\
\hline BUMI & -17.28 & -4.45 & -2.94 & -2.98 & -3.50 & Distressed \\
\hline BYAN & 0.13 & 1.13 & 5.39 & 7.65 & 3.50 & Good \\
\hline DEWA & 1.33 & 0.80 & 0.42 & 0.27 & 0.41 & Distressed \\
\hline DOID & 1.47 & 1.17 & 2.05 & 2.45 & 2.46 & Grey Area \\
\hline GTBO & 6.46 & 6.60 & 4.81 & 6.05 & 3.53 & Good \\
\hline HRUM & 13.85 & 11.50 & 11.85 & 11.33 & 14.40 & Good \\
\hline ITMG & 5.84 & 7.28 & 7.97 & 5.81 & 7.60 & Good \\
\hline KKGI & 8.86 & 12.58 & 12.17 & 7.06 & 7.15 & Good \\
\hline MBAP & 8.67 & 10.87 & 11.60 & 9.35 & 10.89 & Good \\
\hline MYOH & 6.00 & 8.63 & 8.10 & 9.94 & 9.87 & Good \\
\hline PTRO & 2.03 & 3.11 & 3.05 & 3.13 & 3.15 & Good \\
\hline PTBA & 5.35 & 5.54 & 7.29 & 8.37 & 7.52 & Good \\
\hline SMMT & 0.32 & 2.80 & 1.07 & 1.68 & 2.01 & Grey Area \\
\hline TOBA & 3.26 & 2.43 & 3.41 & 3.05 & 1.97 & Good \\
\hline
\end{tabular}

\section{Effect of Z-Score on Stock Price}

During the 2015-2019 period, the lowest coal mining company's share price was 50 rupiah per share. The lowest price was experienced by PT. Bumi Resources Tbk. (BUMI). The highest price of 20,700 rupiahs per share was experienced by PT. Indo Tambang Raya Megah Tbk (ITMG). The average share price of all coal mining companies during 2015-2019 was 2,401 rupiah per share.

Table 4. Descriptive Statistics of Research Variables

\begin{tabular}{crrcccc}
\hline & $\begin{array}{c}\text { Stock } \\
\text { Price }\end{array}$ & Z-Score & WCTA & RETA & EBTA & MVEBVL \\
\hline Mean & 2,401 & 4.259 & 0.104 & 0.216 & 0.103 & 2.089 \\
Maximum & 20,700 & 14.396 & 0.660 & 1.060 & 0.610 & 9.230 \\
Minimum & 50 & -17.280 & -1.450 & -1.060 & -0.600 & -0.540 \\
Std.Dev & 0.169 & 5.113 & 0.294 & 0.415 & 0.173 & 1.935 \\
\hline
\end{tabular}


The lowest Z-Score was -17.28 experienced by PT. Bumi Resources Tbk. (BUMI) 2015. A negative Z-score indicates the company is very likely to go bankrupt. Throughout the research period (2015-2019) BUMI has always had a negative Z-score, as well as PT. Atlas Resources Indonesia Tbk (ARII). The negative Z-score value is caused because the ratio forming the Z-Score is negative, such as in working capital or EBIT. While the highest Z-Score value is 14.39 owned by PT Harum Energy Tbk (HRUM) in 2019. HRUM's Z-score during 2015-2019 was always above 10, indicating a healthy company. The average value (mean) Z-score of 4.25 indicates that in general coal mining companies are in good health, with no potential for bankruptcy.

Regression analysis of the effect of Z-Score on stock prices is carried out by first transforming stock price data into the form of the natural logarithm (Ln), to meet the assumptions underlying the analysis of variance. The results of testing the effect of $Z$ Score on stock prices are shown in table 5

Table 5. Test Result of Z-Score Effect on Stock Price

\begin{tabular}{llll}
\hline Variable & Coefficient & t-statistic & Probability \\
\hline C & 6.058045 & 29.96108 & 0.0000 \\
Z-Score & 0.126659 & 4.154244 & 0.0001 \\
R-squared & 0.172134 & & \\
Adjusted R-Square & 0.162159 & & \\
F-statistic & 17.25774 & & 0.000079 \\
\hline
\end{tabular}

There is evidence that the Z-score has a significant effect on stock prices. The simple regression model that is built accordingly, is shown from the F-statistical significance of 0.000 . The coefficient of determination (R-Squared) of 0.172 indicates that the independent variable (Z-Score) in this study can explain the variability of stock prices by $17 \%$.

The resulting regression equation is: Share Price $=6.058+0.127 Z$-score. The constant is 6.058 with probability $=0.000$. This means that the constant is significant or has significance. When the Z-Score is 0, then the share price is Ln 6.058 or 427.5 Rupiah.

Z-score is calculated from the components of the ratio of WCTA, RETA, EBTA, and MVEBVL. In Table 4 it can be seen that the average WC/TA value of 0.104 indicates that coal mining companies have a net working capital of $10.3 \%$ of the total assets owned. HRUM has the highest WC/TA value of 0.660 , while the lowest WCTA is -1.450 owned by BUMI. A negative WCTA value indicates the company is not liquid because the total current debt is greater than the total current assets.

The RE/TA variable has an average value of 0.216 , indicating that coal mining companies have retained earnings of $21.6 \%$ of total assets. The highest RE/TA value is 1.060 owned by PT Resources Alam Indonesia Tbk (KKGI), while the lowest RE/TA is -1.060 owned by BUMI. The RE/TA KKGI value of 1.06 indicates that the company's income that is not paid by the company to shareholders in the form of dividends is more than the total value of the assets owned. Meanwhile, a negative RE/TA value indicates that the company's share capital has been eroded by the company's losses. 
The average value of the variable EB/TA 0.103 indicates that coal mining companies can generate operating profit (EBIT) of $10.3 \%$ of the total assets owned. The highest EB/TA value is 0.610 which is owned by PT. Bayan Resources Tbk (BYAN), while the lowest EB/TA of -0.6 is owned by PT. Bumi Resources Tbk (BUMI). A positive EB/TA also indicates that the company can earn operating profit. Meanwhile, a negative EB/TA indicates that the company has suffered an operating loss so that it will not be able to meet its debt obligations. The accumulation of large amounts of maturing debt and unfavorable economic conditions including falling demand and commodity prices were the causes.

The variable MVE/BVL has an average value of 2,089, indicating that the value of the shares of a coal mining company is 2,089 times the book value of its debt. The highest MVE/BVL value is 9.23 which is owned by PT. Garda Tujuh Buana Tbk (GTBO), while the lowest MVE/BVL is -0.54 which is owned by PT. Bumi Resources Tbk (BUMI). The positive MVE/BVL GTBO value of 9.23 indicates that the value of the company's shares is valued by the market at 9.23 times the book value of its debt. A negative MVE/BVL value occurs because the company's debt exceeds the value of its assets so that the equity is negative.

\section{The Effect of Z-Score Ratio on Stock Price}

The results of the Chow test, Hausman test, and Lagrange Multiplier test, show that the best panel data regression model in this study is the Random Effect Model (REM) as shown in Table 6 below.

Table 6 Panel Data Regression Model Selection

\begin{tabular}{clcl}
\hline \multirow{2}{*}{ No } & \multicolumn{1}{c}{ Testing } & $\begin{array}{c}\text { Probability/Significance } \\
\text { Value }\end{array}$ & \multicolumn{1}{c}{ Conclusion } \\
\hline 1 & Chow Test & 0,0000 & Fixed Effecet Model \\
2 & Hausman Test & 0,3516 & Random Effect Model \\
3 & Lagrange Multiplier Tes & 0,0000 & Random Effect Model \\
\hline
\end{tabular}

The model is built accordingly because the F-count has a probability of 0.0028 $(<=0.05)$. R-square value of 0.1811 indicates that together WC/TA, RE/TA, EB/TA, and MVE/BVL can explain stock price variability of $18.11 \%$. There are still $81.89 \%$ other factors that affect the share price of coal mining companies and have not been included in this research model.

Table 7. Panel Data Regression Test Results

\begin{tabular}{|c|c|c|c|c|}
\hline Variable & & Coefficient & t-statistic & Probabilty \\
\hline C & & 6.262493 & 17.75456 & 0.0000 \\
\hline WCTA & & 0.173732 & 0.358001 & 0.7213 \\
\hline RETA & & 0.624803 & 1.074104 & 0.2860 \\
\hline EBTA & & 1.652809 & 2.430473 & 0.0173 \\
\hline MVE/BVL & & 0.005166 & 0.064430 & 0.9488 \\
\hline R-squared & & 0.181137 & & \\
\hline $\begin{array}{l}\text { Adjusted } \\
\text { Square }\end{array}$ & R- & 0.140193 & & \\
\hline F-statistic & & & 4.424099 & 0.002784 \\
\hline
\end{tabular}


The regression equation resulting from the estimation of the effect of WC/TA, RE/TA, EB/TA, and MVE/BVL on stock prices is as follows. Share Price $(\mathrm{Y})=6.262+$ 0.174 WCTA + 0.625 RETA + 1.653 EBTA + 0.005 MVEBVL. The constant value of 6.262 with a significance of 0.000 indicates that the constant is significant. Without the influence of the independent variable, the stock price is worth Ln6,262 or 525 rupiahs per share. The value of the WC/TA regression coefficient is 0.174 with a significance of 0.7213 . This shows that WC/TA has no significant effect on stock prices. The regression coefficient value of the RE/TA ratio is 0.625 with a significance of 0.2860 . This shows that RE/TA has no significant effect on stock prices.

The regression coefficient value of the EB/TA ratio is 1.653 with a significance of 0.0173 . This shows that EB/TA has a positive and significant effect on stock prices. If there is an increase of one unit of EB/TA the share price will increase by $1.653 \%$. The regression coefficient value of the MVE/BVL ratio is 0.005 with a significance of 0.9488 . This shows that MVE/BVL has no significant effect on stock prices.

The results of the analysis of the Altman Z-Score method show that there is a potential for bankruptcy of coal mining companies in 2015-2019, namely in companies with stock exchange codes ARII, BUMI, and DEWA. The prediction results are in line with the company's share price which fell to Rp50 for BUMI and DEWA, while ARII's share price was above Rp50 but was in a relatively low range, namely Rp400-700 per share or below the industry average. Healthy companies that do not have the potential to go bankrupt, such as PTBA and ITMG, have high share prices.

The results of the regression analysis show that the Z-Score has a significant effect on stock prices. Z-Score is usually used to assess the level of bankruptcy of a company, which indirectly also reflects the company's financial performance. The better the Z-Score of a company, the healthier the company. The healthier the condition of a company, the more investors are interested in owning the company's shares. Stocks that are in high demand will increase in price. The results of this study are in line with Wulandari et al. (2017) who examined mining companies listed on the IDX for the 2012-2015 period and Ramadhan and Wuryani (2018) on state-owned companies listed on the IDX for the 2012-2016 period. The similarity of the type of industry and the Altman model used in the research as well as the country in which the research was conducted allows for similar research results.

It was found that WC/TA had no significant effect on stock prices. These results are in line with research by Radityatama \& Mustafa (2019) on plantation sector companies on the IDX for the 2014-2018 period and Sukmawati et al. (2014) on banking sector companies on the Indonesia Stock Exchange in 2012. The similarity of the results of the study with previous research is because the company must make a large investment in its fixed assets.

The results showed that the RE/TA ratio had no significant effect on stock prices. This result is in line with Ardian and Khoirudin's (2014) on manufacturing sector companies on the IDX for the period 2008-2013 and Endri and Yerianto's (2019) research on gas mining companies listed on the IDX for the period 2012-2016. Retained earnings are closely related to the company's dividend policy. If investors do not pay 
attention to retained earnings, it means that investors also do not pay attention to dividend policy. This means that dividends are considered irrelevant, do not affect stock prices.

It was found that EB/TA had a positive effect on stock prices. A high EB/TA ratio shows the company can utilize assets well to generate operating income. This result is in line with Lestari et al. (2016) who examined chemical sector companies listed on the IDX for the 2009-2014 period. It is also in line with Radityatama and Mustafa's research (2019) which examined plantation sector companies on the IDX for the 2014-2018 period. The company's ability to print operating profit is an attraction for investors because they believe the company has a good performance.

The results of the analysis show that MVE/BVL has no significant effect on stock prices. This result is in line with Ardian \& Khoirudin (2014) who examined manufacturing sector companies on the IDX for the period 2008-2013. The results of this study are also in line with Lestari et al. (2016) who examined chemical sector companies listed on the IDX for the 2009-2014 period. Investors tend to look more at the company's sales or earnings and do not see the company's debt in their investment decisions.

\section{E. CONCLUSION}

Based on the results of the study, there are 3 (three) coal mining companies that have the potential to experience bankruptcy, namely ARII, BUMI, and DEWA. Two companies are included in the gray area category, namely DOID and SMMT. While the other 12 companies are in good health. Z-Score affects the share price of coal mining companies. WC/TA, RE/TA, and MVE/BVL ratios have no significant effect on stock price fluctuations. Meanwhile, the EB/TA ratio has a positive and significant impact on the share price of coal mining companies in 2015-2019.

The stock price shows the value of the company. If management wants stock prices to continue to increase, the company needs to pay attention to the potential for bankruptcy of the company through the Z-score value. The higher the Z-score, the safer the company from potential bankruptcy, thereby increasing investor interest in investing so that stock prices tend to increase. For further research, research can be carried out in different sectors or sub-sectors. Future research can replace the measurement of potential bankruptcy with other approaches. This study has a relatively low coefficient of determination. Therefore, further research should add other independent variables such as dividend policy, capital structure policy, or include macroeconomic factors as variables that affect stock prices.

\section{REFERENCES}

1. Adnan, M. A., \& Kurniasih, E. (2000). Analisis Tingkat Kesehatan Perusahaan untuk Memprediksi Potensi Kebangkrutan pada Pendekatan Altman (Kasus pada Sepuluh Perusahaan di Indonesia). Jurnal Akuntansi dan Auditing Indonesia, 4(2), 131-151. 
2. Altman, E. (1968). Financial Ratios,Discriminant Analysis and the Prediction of Corporate Bankruptcy. Journal of Finance, 23, 589-609.

3. Prihadi, T. (2011). Analisis Laporan Keuangan Teori dan Aplikasi. Jakarta: PPM.

4. Altman, E., Hartzell, J., \& Peck, M. (1995). Emerging Markets Corporate Bonds: A Scoring System. New York: Salomon Brothers Inc.

5. Ardian, A., \& Khoiruddin, M. (2014). Pengaruh Analisis Kebangkrutan Model Altman Terhadap Harga Saham Perusahaan Manufaktur. Management Analysis Journal, 1(2), 1-14.

6. Babatunde, A. A., Akeju, J. B., \& Malomo, E. (2017). The Effectiveness of Altman's Z-Score in Predicting Bankruptcy of Quoted Manufacturing Companies in Nigeria. European Journal of Business, Economics and Accountancy, 5(5), 74-83.

7. Brigham, E. F., \& Houston, J. F. (2011). Dasar-dasar Manajemen Keuangan Terjemahan. Jakarta: Salemba Empat.

8. Caroline, L., \& Laturette, K. (2019). Comparative Analysis of Z-Score and Springate Altman Models on Registered Coal Companies BEI in 2011-2015. Research in Management And Accounting, 2(2), 56-66.

9. Endri, \& Yerianto, D. (2018). Determinants of Bankruptcy Prediction and Implication on Stock Prices in Oil and Gas Mining Sectors in Indonesia Stock Exchange Period 2012-2016. International Journal of Management Sciences and Business Research, 8(4), 11-17.

10. Gosh, P. (2013). Testing of Altman's Z - Score model, a Case Study of Dunlop India Ltd. Paripex-Indian Journal Of Research, 3(4), 219-220.

11. Hanafi, M., \& Halim, A. (2007). Analisis Laporan Keuangan. Yogyakarta: UPP STIM YKPN.

12. Iladina, F., Mardani, R. M., \& Khoirul ABS, M. (2018). Analisis Metode Altman ZScore Sebagai Alat Prediksi Kebangkrutan dan Pengaruhnya Terhadap Harga Saham pada Perusahaan Tekstil dan Garmen Yang Terdaftar di Bursa Efek Indonesia Tahun 2014-2016. e-Jurnal Riset Manajemen Prodi Manajemen Fakultas Ekonomi Unisma, 7(2), 11-25.

13. Kadim, A., \& Nardi, S. (2018). Pengaruh Analisa Kesahatan dan Kebangkrutan dengan Pendekatan Altman Z-Score terhadap Harga Saham Industri Konstruksi di Indonesia yang Listing di BEI periode 2013-2017. JURNAL SEKURITAS (Saham, Ekonomi, Keuangan dan Investasi), 1(4), 52-65

14. Karaca, S., \& Ozen, E. (2017). Financial Failure Estimation of Companies in BIST Tourism Index by Altman Model and its Effect on Market Prices. BRAND. Broad Research in Accounting, Negotiation, and Distribution, 8(2), 11-23.

15. Lestari, D. S., Oktaviani, F. O., \& Arafah, W. (2016). Financial Distress Prediction with Altman Z-Score and Effect on Stock Price: Empirical Study on Companies Subsectors Chemical Listed In Indonesia Stock Exchange Period 2009-2014. International Journal of Business and Management Invention, 5(8), 30-39.

16. Ozyesil, M. (2020). A Relationship between Altman's Z Scores and Stock Price Performance: A Review on Listed Companies in Bist-30 Index. SSRG International Journal of Economics and Management Studies (SSRG-IJEMS), 7(2), 179-186. 
17. Platt, H., \& Platt, M. (2002). Predicting Corporate Financial Distress: Relections on Choice-Based Sample Bias. Journal of Economics and Finance, Springer; Academy of Economics and Finance, 26(2), 184-199.

18. Primasari, N. S. (2017). Analisis Altman Z-Score, Grover Score, Springate, Dan Zmijewski Sebagai Signaling Financial Distress (Studi Empiris Industri BarangBarang Konsumsi di Indonesia). Accounting and Management Journal, 1(1), 23-43.

19. Radityatama, M. F., \& Mustafa, M. (2019). The Effect Of Altman Z - Score Financial Ratio On Stock Price (Study On Go Public Plantation Subsector Companies in Indonesia Stock Exchange). Dinasti International Journal of Digital Business Management, 1(1), 43-55.

20. Ramadhan, F. A., \& Wuryani, E. (2018). Pengaruh Prediksi Kebangkrutan Terhadap Harga Saham Perusahaan. Jurnal Akuntansi AKUNESA, 7(1), 1-23.

21. Sukmawati, N. D., Adiputra, P. I., \& Darmawan, S. N. (2014). Pengaruh RasioRasio Dalam Model Altman Z Score Terhadap Harga Saham (Studi pada Perusahaan Perbankan yang Go Public di Bursa Efek Indonesia). e-Journal S1 Ak Universitas Pendidikan Ganesha, 2(1), 1-11.

22. Syamni, G., Abd. Madjid, M., \& Siregar, V. V. (2018). Bankruptcy Prediction Models and Stock Prices of the Coal Mining Industry in Indonesia. Etikonomi, 17(1), 57-68.

23. https://www.idx.go.id. Accessed November 12, 2020.

24. https://www.indonesia-investments.com/id/bisnis/komoditas/batu-bara. Accessed November 12, 2020. 